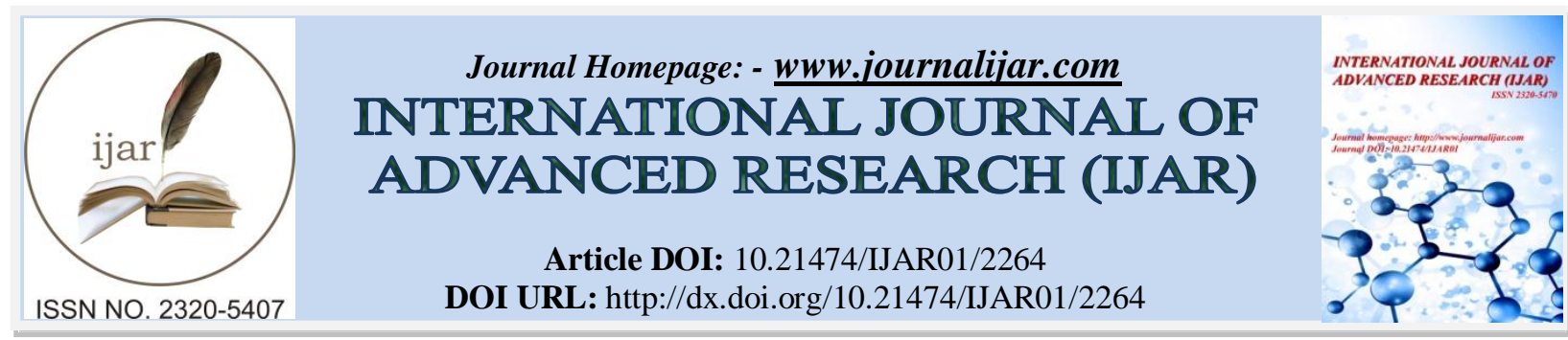

RESEARCH ARTICLE

\title{
ON-FARM TRIALS OF FARMER'S VARIETY: TOOL FOR PERFORMANCE EVALUATION AND ADOPTION OF VARIETY IN NEW AREAS.
}

\section{Mahesh B Chodvadiya, Satya Singh, "Hardev Choudhary, Noushad Parvez, Ravikumar RK and Dadaji Ramaji Khobragade.}

National Innovation Foundation-India, Satellite complex, Jodhpur Tekra, Premchand Nagar Road, Satellite, Ahmedabad-380 015, Gujarat, INDIA.

\section{Manuscript Info}

\section{Manuscript History}

Received: 29 September 2016

Final Accepted: 30 October 2016

Published: November 2016

Key words:-

Farmer's variety, On-farm trials, Adoption, Yield attributing traits, Paddy.

\section{Abstract}

In the year 2014, during Kharif season trials were conducted to determine nature of output of farmer's rice variety under local condition and to evaluate rate of adoption among users. Rice variety "DRK" that was developed by innovative farmer Shri Dadaji Ramaji Khobragade of Maharashtra was shared among farmers. The trial was conducted at twelve different farmers' field who had volunteered in Gandhinagar district of Gujarat state, India. The average yield of this variety was found to be $8.51 \pm 0.2 \mathrm{t} / \mathrm{ha}$ with highest yield to the tune of 10 tonnes per hectare. A positive correlation was observed between the yield and yield attributing traits like number of tillers and reproductive tillers / hill, panicle length, secondary branches of panicle, number of spikelets / panicle showing their direct effect on yield. Less incidence of grain smut disease was also observed in DRK variety. Farmers during the first harvest obtained better market price for the produce. The farmers in study region started preserving seeds and nearby farmers sought for it as well. Subsequently, this information was shared and two farmer group discussions were held in the year 2015. It was found that the area under DRK rice variety increased over 80 fold spread across six districts owing to positive impact in farmers' field. The study reinforced importance of farmers' participation in on-farm trials to enrich and promote suitable intervention.

Copy Right, IJAR, 2016,. All rights reserved.

\section{Introduction:-}

The plant varieties in the form of farmer's variety have been in existence in India for a long time. "Farmers' varieties" are defined as varieties that have traditionally been cultivated and developed by farmers in their fields or varieties that are a wild relative or land race of any variety about which farmers possess common knowledge (Cullet and Koluru, 2003). Farmers around the world have been selecting and conserving varieties of different crop plants that they cultivated. This process has generated a rich wealth of varieties in each crop plant (Bala Ravi, 2004). The role of farmer in developing new variety as well as its dissemination is very important for increasing cultivation area under developed new crop variety. These creative environmental friendly, locally available technologies can lead for inclusive growth (Gupta, 2013).

Corresponding Author:- Hardev Choudhary. Address:- National Innovation Foundation-India, Satellite complex, Jodhpur Tekra, Premchand Nagar Road, Satellite, Ahmedabad-380 015, Gujarat, INDIA 
Rice (Oryza sativa L.) is the world's single most important food crop and the staple food for more than half of the world's population (IRRI, 2006). More than 90\% world rice is grown and consumed in Asia (Tyagi et al., 2004). The total area planted under rice crop in India was 44.10 million ha accounting for around $4.3 \%$ area of the total area for food grains cultivation (INDIASTAT, 2014-15), which is the largest in the world as against the total area of 161.70 million ha (STATISTA, 2013-14). India is the leading exporter of rice for the years 2013-2015 (INDIASTAT, 2015). Gujarat state with a total area of 786.00 ('000ha) and 1830.9 ('000 tonnes) rice production contributes to a tune of $1.735 \%$ to the national production of rice. In order to achieve the targets of food grains production in the country, a need of the day is to promote farmers' developed varieties as alternatives and reduce the technology gap between formal and informal system. The significance of farmers' developed varieties lies in the fact that they are rich in their nutritional and medicinal values apart from being a huge resource of genetic biodiversity for further research (Lushington, 2012).

Dadaji Ramji Khobragade is an innovative farmer hailing from Chandrapur district of Maharashtra. He has developed and conserved several varieties of rice and was awardednational second award in the third National Biennial Competition of National Innovation Foundation- India in the year 2005 for his exemplary work by former President of India Late. Dr. A.P.J. Abdul Kalam. In 2009 he was again recognized for his contribution in diffusion of the varieties (NIF database, 2005, 2009). FORBES magazine listed him amongst seven most powerful rural entrepreneurs in 2010. He is a highly recognized farmer with several awards to his credit including a cash reward of 1.0 lakh from the state government and five acres land to multiply the seeds of his variety.

Lack of suitable technologies to meet location specific demand of farming community and to enhance their adoption rate there is need to undertake dissemination, field demonstration, and farmers' participatory research and training programs (Kadivendi et al., 2015; Ghimire et al., 2015). The purpose of present study is to focus on farmers' lead innovations for sustainable agricultural development in the country and to study the adoption of farmers' varieties in suitable areas, the problems and constrains in adopting the technologies and to device suitable strategies for the dissemination of such varieties. Keeping in view the significance of promotion of grassroots technologies the present study attempts to provide environmental friendly and locally available technology based on its performance evaluation through on-farm demonstration trials by involving farming community and get benefited with its higher commercial returns on their produce.

\section{Materials \& Methods:-}

Field trials were carried out in 12 different farmers' field of two villages of Gandhinagar district $\left(23.223^{\circ} \mathrm{N}\right.$, $72.650^{\circ} \mathrm{E}$ ) of Gujarat condition during Kharif 2014 . The soil of the study area was sandy clay loam in texture. The farmer's developed rice variety-DRK was used as a test variety to check the adaptability under local condition. The package of practices of local farmers was adopted to stand good crop. The size of each demonstration plot was $40 \mathrm{x}$ $40 \mathrm{~m}^{2}$. The farmers were selected through visit to their fields, group discussion and farmers meeting in villages. The seed material was procured from Shri Dadaji Ramaji Khobragade who had developed number of rice varieties. Observations pertaining to agronomic and yield attributing traits (Table 1) were recorded from 25 different randomly selected plants from each plot. The grain yield, yield components and other characteristics were determined according to the method of Standard Evaluation System for Rice (IRRI, 1988). All the data collected were subjected to statistical analysis ANOVA using Graphpad Prism 5 software to find out significant differences between the means followed by Bonferroni's post hoc test. Correlation coefficients were also calculated to find out correlation between different parameters studied and yield. All the data is presented in mean \pm SE unless otherwise stated.

Table: 1 Evaluated parameters in the study under field condition.

\begin{tabular}{|l|l|}
\hline Plant height $(\mathrm{cm})$ & $\begin{array}{l}\text { Measured height from the base of the plant to the top of the latest } \\
\text { spikelet on the panicle, excluding awn }\end{array}$ \\
\hline Leaf blade length $(\mathrm{cm})$ & $\begin{array}{l}\text { Measured length from the leaf base to the leaf tip of the fully expanded } \\
\text { leaves }\end{array}$ \\
\hline Leaf blade width $(\mathrm{cm})$ & Measured at the widest point of the leaf \\
\hline Number of tillers per hill & Counted total number of tillers at the maturity stage \\
\hline Number of reproductive tillers per hill & Counted number of tillers with panicles \\
\hline Panicle length $(\mathrm{cm})$ & $\begin{array}{l}\text { Measured from the base of the lowest spikelet to the tip of the latest } \\
\text { spikelet on the panicle, excluding awn }\end{array}$ \\
\hline Number of secondary branches per & Counted total number of secondary branches in sampled panicles \\
\hline
\end{tabular}




\begin{tabular}{|l|l|}
\hline panicle & \\
\hline Number of spikelets per panicle & Counted total number of spikelets in sampled per panicle \\
\hline Grain lengthand width $(\mathrm{mm})$ & Measured using Vernier caliper \\
\hline 1000 grains weight $(\mathrm{g})$ & $\begin{array}{l}1000 \text { grains were counted from sampled plants of each replicate and } \\
\text { weighed }\end{array}$ \\
\hline Yield (q/ha) & Weighed the production of each plot \\
\hline
\end{tabular}

\section{Results and Discussion:-}

The performance of the variety DRK was very good in all the 12 fields at both the locations tested. The mean plant height recorded was $113.01 \pm 0.81 \mathrm{~cm}$, with a minimum $(109 \pm 0.60 \mathrm{~cm})$ and maximum $(118 \pm 0.96 \mathrm{~cm})$ at location 1 and 2 respectively (Table 2, figure 1). The ANOVA table shows there is significant difference in plant height (Table $3)$. A positive correlation coefficient $(\mathrm{r}=0.118$; $\mathrm{p}<0.05)$ shows the direct effect of plant height on the yield of the variety. The plant height has significant effect on yield as it not only determines lodging behavior but also plays important role in determining the response of the plant to nitrogen apart from facilitating light penetration which may increase photosynthesis (Chandrasekaran et al., 2007) thus exerting effect on yield and production. Mean leaf blade length $(59.25 \pm 0.75 \mathrm{~cm})$ and mean blade width $(1.1 \pm 0.05 \mathrm{~cm})$ with a correlation coefficient of $(\mathrm{r}=-0.44$; $\mathrm{p}<0.05)$ and $(\mathrm{r}=0.18 ; \mathrm{p}<0.05)$ respectively were observed categorizing it as a long leaved variety with medium width (PPVFRA, 2007). The negative correlation of leaf blade length with that of yield is probably balanced with the uniformity in leaf blade width that has a positive effect on yield. Generally the leaf length is more variable than leaf width (Kuo and Li, 1994) as observed in the present study. Leaf length is often associated with leaf angle and longer leaves generally tend to droop. The preference is for short and uniform distributed leaves that utilize maximum incident light for photosynthesis, hence, maximizing the yield. The capacity of photosynthetic leaves to supply assimilate during ripening period of grains and the capacity of developing grains to accumulate the imported accumulate play important role in determining the grain weight, thus affecting the total yield (Ntanos and Koutroubas, 2002).

The most important yield attributing traits in rice are number of tillers, number of reproductive tiller, panicle length and number of spikelets per panicle which are directly proportional to yield (Akram et al., 1982; Surek \& Beser, 1996 and Manzoor et al., 2006). Tillering plays an important role in increasing yield as it is directly proportional to the number of panicles per unit area (Smith and Dilday, 2003). In present study, the mean number of tillers per hill were $16.7 \pm 0.74$ while number of reproductive tillers recorded were $15.01 \pm 0.77$ (Table 2, Figure 1). Both these traits showed high positive correlation coefficient of $r=0.653$ and $0.630(p<0.05)$ respectively $($ Table 2$)$ showing a direct positive effect on production. Tillers per unit area play a pivotal role in deciding physical capacity of yields and account for 60 percent variations in grain yield in rice (Kaur and Dhaliwal, 2014). Results congruent with the present study have been reported by Anbanandan et al., (2009); Singh et al.,(2010) and Dutta et al., (2013).

The panicle length ranged between 14 to $22 \mathrm{~cm}$ with a mean value of $18.7 \pm 0.69 \mathrm{~cm}$ and a correlation coefficient $\mathrm{r}=$ $0.74(\mathrm{p}<0.05)$ showing the maximum effect on yield (Table 2, 3; Figure 1). Similar effects on yield was observed in case of number of secondary branches per panicle with a mean of $11.4 \pm 0.62$ and correlation coefficient $r=0.68$ $(p<0.05)$ (Table 2, 4; Figure 1). The number of spikelets per panicle ranged between 296 to 479 with a mean of 371 \pm 20.6 and a high positive correlation coefficient $r=0.610(\mathrm{p}<0.05)$. The highest numbers of reproductive tillers per hill (20.2), number of spikelets per panicle (479) and panicle length $(22.4 \mathrm{~cm})$ were observed in the plot from where maximum yield (10 t/ha) was obtained showing strong effect of these attributes on the yield (Table 2, 3, Figure 2). These results are in agreement with the earlier observations of Karim et al., (2007), Prajapati et al., (2011) and Singh et al., (2011). The number of panicles per unit area, number of spikelets per panicle and percentage filled grains are primary determinants of rice yield (Zeng and Shannon, 2000; Jeng et al., 2006; Singh et al., 2011) although affected by environmental factors as well as agronomic practices. The variations observed in panicle length, secondary branches and number of spikelets at the two locations of the present study may be due to the developmental and functional differences in the vascular bundles between primary and secondary branches (Jeng $e t$ al., 2006) or due to cumulative effects of environment and agronomic practices.

The grain length ranged between 0.52 to $0.66 \mathrm{~cm}$ with a mean of $0.61 \pm 0.01 \mathrm{~cm}(\mathrm{r}=0.33 ; \mathrm{p}<0.05)$ while minimum and maximum grain width observed were 0.20 and $0.25 \mathrm{~cm}$ respectively with a mean of $0.22 \pm 0 \mathrm{~cm}(\mathrm{r}=0.23$; $\mathrm{p}<0.05)$ categorizing it under the short and medium type variety based on grain length and width (PPVFRA, 2007). The physical dimensions of rice are pivotal to those engaged in rice industry as they are important in marketing and 
grading, in developing new rice varieties, in cleaning and grading equipment, in drying and processing operations (Agrifacts, 2007; Tokpah, 2010). Rice quality based on uniformity in shape, size and overall appearance is an important quality attribute to farmers, rice buyers, millers and consumers.

The mean 1000 grain weight was $20.8 \pm 0.4 \mathrm{~g}$, ranging between 18 to $22 \mathrm{~g}$ at the farmers field of two locations tested $(\mathrm{r}=0.44 ; \mathrm{p}<0.05)$ (Table 2,3). The mean yield per hectare recorded was $8.5 \pm 0.23$ tons with a minimum yield of 6.7 tons/ha and maximum of 10 tons/ha. The low yield at one farmer's location was due to late sowing and poor irrigation facility. Yield is a complex character, influenced by various agronomic traits that are interrelated and highly influenced by environmental factors (Eswara Reddy et al., 2013; Jambhulkar and Bose, 2014). The higher yield at majority of farmers' field possibly resulted from more panicles per unit area, higher 1000 seed weight, better agronomic practices followed by respective farmers. 1000 grain weight and seed size can vary from one crop to another, between varieties of the same crop and even from year to year or from field to field of the same variety(Anonymous, 2007) as observed in the present study where a significant difference in yield was observed at farmers filed of two locations (Table 2, 3).

Table 2:- Performance of DRK rice variety at farmers' field (mean \pm SE) in Gandhinagar (Gujarat) along with

\begin{tabular}{|c|c|c|c|c|c|c|c|c|c|c|c|c|}
\hline Traits & $\begin{array}{l}\text { PH } \\
(\mathbf{c m})\end{array}$ & $\begin{array}{l}\text { LBL } \\
\text { (cm) }\end{array}$ & $\begin{array}{l}\text { LB } \\
W \\
(\mathbf{c m})\end{array}$ & TP & RTP & $\begin{array}{l}\text { PL } \\
(\mathbf{c m})\end{array}$ & SBP & SP & $\begin{array}{l}\text { GL } \\
(\mathbf{c m})\end{array}$ & $\begin{array}{l}\text { GW } \\
\text { (cm) }\end{array}$ & $\begin{array}{l}\text { 1000 } \\
\text { GWt } \\
\text { (gra } \\
\text { ms) }\end{array}$ & $\begin{array}{l}\text { Yield } \\
\text { (t/ha) }\end{array}$ \\
\hline & $\begin{array}{l}113.1 \\
\pm 0.8\end{array}$ & $\begin{array}{l}59.3 \pm \\
0.8\end{array}$ & $\begin{array}{l}1.2 \pm \\
0.1\end{array}$ & $\begin{array}{l}16.7 \pm \\
0.7\end{array}$ & $\begin{array}{l}15.1 \pm \\
0.8\end{array}$ & $\begin{array}{l}18.7 \pm \\
0.7\end{array}$ & $\begin{array}{l}11.4 \pm \\
0.6\end{array}$ & $\begin{array}{l}371.0 \pm \\
20.6\end{array}$ & $\begin{array}{l}0.61 \pm \\
0.01\end{array}$ & $\begin{array}{l}0.22 \pm \\
0.0\end{array}$ & $\begin{array}{l}20.8 \pm \\
0.4\end{array}$ & $\begin{array}{l}8.51 \pm \\
0.2\end{array}$ \\
\hline
\end{tabular}

Correlation coefficients

\begin{tabular}{|c|c|c|c|c|c|c|c|c|c|c|c|c|}
\hline PH & & & & & & & & & & & & \\
\hline LBL & 0.041 & & & & & & & & & & & \\
\hline LBW & 0.312 & 0.091 & & & & & & & & & & \\
\hline TP & 0.127 & $\overline{-}-175$ & $\begin{array}{l} \\
0.141\end{array}$ & & & & & & & & & \\
\hline RTP & 0.079 & $\begin{array}{l}-115 \\
0.11\end{array}$ & 0.045 & $\begin{array}{l}0.953 \\
* *\end{array}$ & & & & & & & & \\
\hline PL & 0.235 & 0.125 & 0.251 & $\begin{array}{l}0.543 \\
*\end{array}$ & $\begin{array}{l}0.566 \\
*\end{array}$ & & & & & & & \\
\hline SBP & $\begin{array}{l}0.624 \\
*\end{array}$ & $\overline{-}-037$ & 0.085 & $\begin{array}{l}0.708 \\
* *\end{array}$ & $\begin{array}{l}0.636 \\
*\end{array}$ & $\begin{array}{l}0.634 \\
*\end{array}$ & & & & & & \\
\hline SP & $\begin{array}{l}0.653 \\
*\end{array}$ & $\begin{array}{l}- \\
0.096\end{array}$ & 0.377 & $\begin{array}{l}0.641 \\
*\end{array}$ & $\begin{array}{l}0.696 \\
*\end{array}$ & $\begin{array}{l}0.673 \\
*\end{array}$ & $\begin{array}{l}0.741 \\
*\end{array}$ & & & & & \\
\hline$\overline{\text { GL }}$ & $\begin{array}{l}0.640 \\
*\end{array}$ & $\overline{-}-0.058$ & $\begin{array}{l}- \\
0.108\end{array}$ & $\begin{array}{l}0.609 \\
*\end{array}$ & $\begin{array}{l}0.578 \\
*\end{array}$ & 0.320 & $\begin{array}{l}0.737 \\
*\end{array}$ & $0.720^{*}$ & & & & \\
\hline$\overline{G W}$ & 0.173 & 0.399 & 0.018 & 0.331 & 0.337 & 0.458 & $\begin{array}{l}0.625 \\
*\end{array}$ & 0.274 & 0.407 & & & \\
\hline $\begin{array}{l}\text { 1000 } \\
\text { GWt }\end{array}$ & -0.259 & $\overline{-}-037$ & $\begin{array}{l} \\
0.111\end{array}$ & $\begin{array}{l}0.666 \\
*\end{array}$ & $\begin{array}{l}0.667 \\
*\end{array}$ & $\begin{array}{l}0.571 \\
*\end{array}$ & 0.219 & 0.308 & 0.090 & 0.233 & & \\
\hline Yield & 0.188 & $\begin{array}{l}- \\
0.442\end{array}$ & 0.189 & $\begin{array}{l}0.653 \\
*\end{array}$ & $\begin{array}{l}0.630 \\
*\end{array}$ & $\begin{array}{l}0.737 \\
* *\end{array}$ & $\begin{array}{l}0.679 \\
*\end{array}$ & $0.610^{*}$ & 0.325 & 0.232 & 0.436 & \\
\hline
\end{tabular}

PH- plant height; LBL- leaf blade length; LBW-leaf blade width; TP- no. of tillers/hill; RTP- no. of reproductive tillers/hill; PL- panicle length; SBP- secondary branches/panicle; SP- number of spikelets /panicle; GL- grain length; GW- grain width; 1000GWt- 1000 grain weight. ** Significant at $0.01 ; *$ Significant at 0.05 
Table 3:- Analysis of Variance (ANOVA) for yield attributing traits in DRK rice variety at farmers' field in Gandhinagar (Gujarat).

\begin{tabular}{|c|c|c|c|c|c|c|c|c|}
\hline Traits & Source of variation & df & SS & MS & $\mathbf{F}$ & R squared & $P$ value & $\begin{array}{l}\text { P-value } \\
\text { summary }\end{array}$ \\
\hline PH & $\begin{array}{l}\text { Treatment } \\
\text { Residual } \\
\text { Total }\end{array}$ & $\begin{array}{l}11 \\
288 \\
299\end{array}$ & $\begin{array}{l}2300 \\
4300 \\
6600\end{array}$ & $\begin{array}{l}210 \\
15 \\
-\end{array}$ & 14 & 0.35 & $<0.0001$ & $* * *$ \\
\hline LBL & $\begin{array}{l}\text { Treatment } \\
\text { Residual } \\
\text { Total }\end{array}$ & $\begin{array}{l}11 \\
288 \\
299\end{array}$ & $\begin{array}{l}2000 \\
5600 \\
7600\end{array}$ & $\begin{array}{l}180 \\
19 \\
-\end{array}$ & 9.3 & 0.26 & $<0.0001$ & $* * *$ \\
\hline LBW & $\begin{array}{l}\text { Treatment } \\
\text { Residual } \\
\text { Total }\end{array}$ & $\begin{array}{l}11 \\
288 \\
299\end{array}$ & $\begin{array}{l}7.3 \\
5.0 \\
12\end{array}$ & $\begin{array}{l}0.67 \\
0.017 \\
-\end{array}$ & 38 & 0.59 & $<0.0001$ & $* * *$ \\
\hline TP & $\begin{array}{l}\text { Treatment } \\
\text { Residual } \\
\text { Total }\end{array}$ & $\begin{array}{l}11 \\
288 \\
299\end{array}$ & $\begin{array}{l}1900 \\
2000 \\
3900\end{array}$ & $\begin{array}{l}170 \\
7.0 \\
-\end{array}$ & 25 & 0.49 & $<0.0001$ & $* * *$ \\
\hline RTP & $\begin{array}{l}\text { Treatment } \\
\text { Residual } \\
\text { Total }\end{array}$ & $\begin{array}{l}11 \\
288 \\
299 \\
\end{array}$ & $\begin{array}{l}2100 \\
1900 \\
4000 \\
\end{array}$ & $\begin{array}{l}190 \\
6.7 \\
-\quad \\
\end{array}$ & 29 & 0.52 & $<0.0001$ & $* * *$ \\
\hline PL & $\begin{array}{l}\text { Treatment } \\
\text { Residual } \\
\text { Total }\end{array}$ & $\begin{array}{l}11 \\
288 \\
299\end{array}$ & $\begin{array}{l}1500 \\
2100 \\
3600\end{array}$ & $\begin{array}{l}140 \\
7.3 \\
-\end{array}$ & 19 & 0.42 & $<0.0001$ & $* * *$ \\
\hline SBP & $\begin{array}{l}\text { Treatment } \\
\text { Residual } \\
\text { Total }\end{array}$ & $\begin{array}{l}11 \\
288 \\
299 \\
\end{array}$ & $\begin{array}{l}1300 \\
1600 \\
2800\end{array}$ & $\begin{array}{l}120 \\
5.4 \\
- \\
\end{array}$ & 21 & 0.45 & $<0.0001$ & $* * *$ \\
\hline SP & $\begin{array}{l}\text { Treatment } \\
\text { Residual } \\
\text { Total }\end{array}$ & $\begin{array}{l}11 \\
288 \\
299 \\
\end{array}$ & $\begin{array}{l}1400000 \\
790000 \\
2200000\end{array}$ & $\begin{array}{l}130000 \\
2700 \\
-\end{array}$ & 47 & 0.64 & $<0.0001$ & $* * *$ \\
\hline GL & $\begin{array}{l}\text { Treatment } \\
\text { Residual } \\
\text { Total }\end{array}$ & $\begin{array}{l}11 \\
288 \\
299 \\
\end{array}$ & $\begin{array}{l}0.51 \\
1.8 \\
2.3 \\
\end{array}$ & $\begin{array}{l}0.046 \\
0.0063 \\
-\end{array}$ & 7.3 & 0.22 & $<0.0001$ & $* * *$ \\
\hline GW & $\begin{array}{l}\text { Treatment } \\
\text { Residual } \\
\text { Total }\end{array}$ & $\begin{array}{l}11 \\
288 \\
299\end{array}$ & $\begin{array}{l}0.053 \\
0.60 \\
0.66\end{array}$ & $\begin{array}{l}0.0048 \\
0.0021 \\
-\end{array}$ & 2.3 & 0.08 & 0.0110 & $*$ \\
\hline 1000GWt & $\begin{array}{l}\text { Treatment } \\
\text { Residual } \\
\text { Total }\end{array}$ & $\begin{array}{l}11 \\
288 \\
299\end{array}$ & $\begin{array}{l}600 \\
1300 \\
1900 \\
\end{array}$ & $\begin{array}{l}54 \\
4.4 \\
- \\
\end{array}$ & 12 & 0.32 & $<0.0001$ & $* * *$ \\
\hline
\end{tabular}

PH- plant height; LBL- leaf blade length; LBW-leaf blade width; TP- no. of tillers/hill; RTP- no. of reproductive tillers/hill; PL- panicle length; SBP- secondary branches/panicle; SP- number of spikelets /panicle; GL- grain length; GW- grain width; 1000GWt- 1000 grain weight

The variety under the present study had fetched good market prices of Rs 1900 to 2000 / quintal as compared to minimum support price (MSP) of Rs 1400/q and 1450/q in 2014 and 2015 (INDIASTAT, 2015) respectively due to its excellent rice recovery value and good cooking quality. Traditional cultivars are still popular for their palatability and reliable yield performance even under low input conditions (Shiva et al., 1995). 
Figure 1:- Performance of DRK paddy variety at twelve different farmers' field in Gandhinagar (Gujarat)
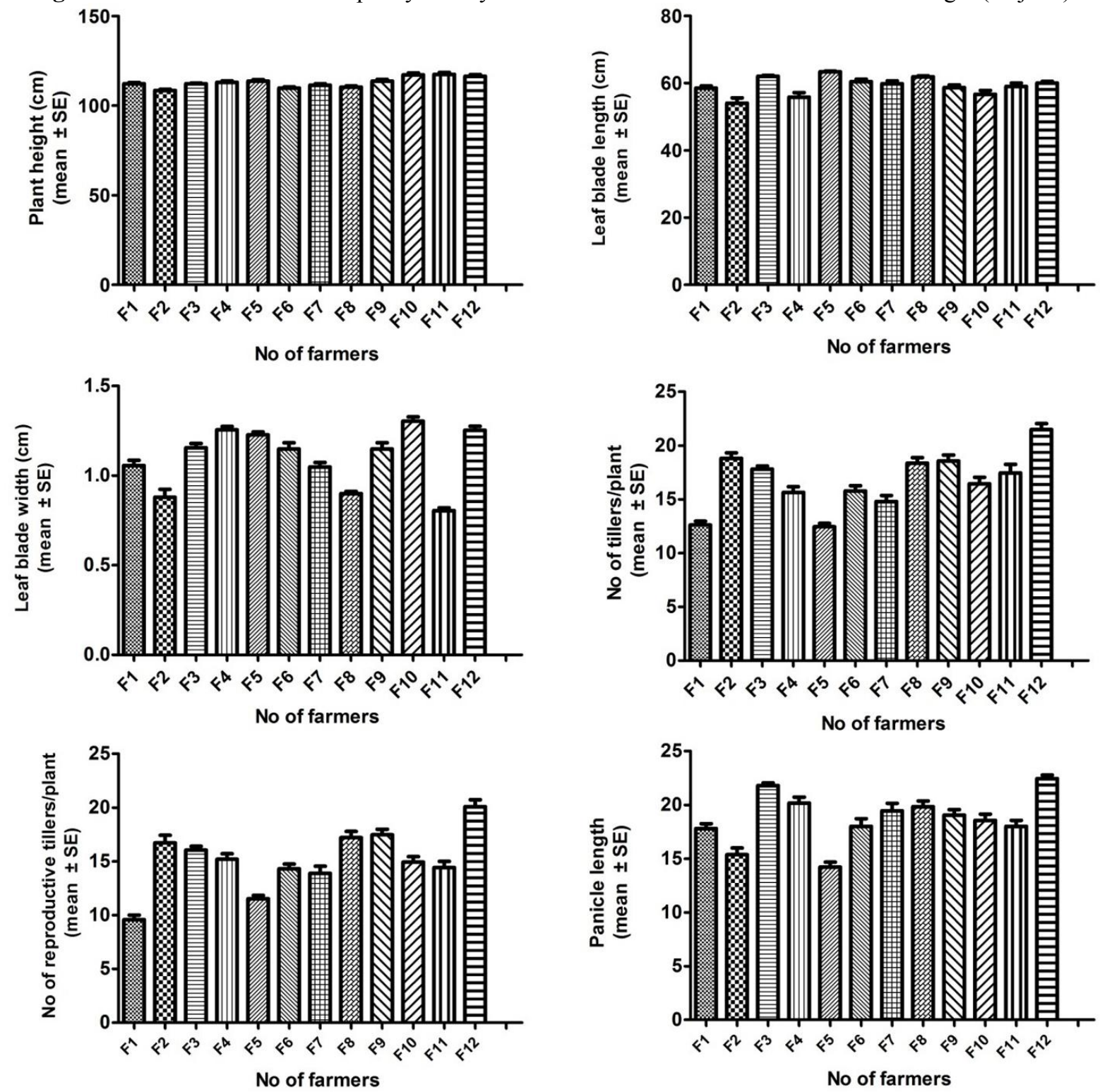

Figure 1 (contd): Performance of DRK paddy variety at twelve different farmers' field in Gandhinagar (Gujarat). 

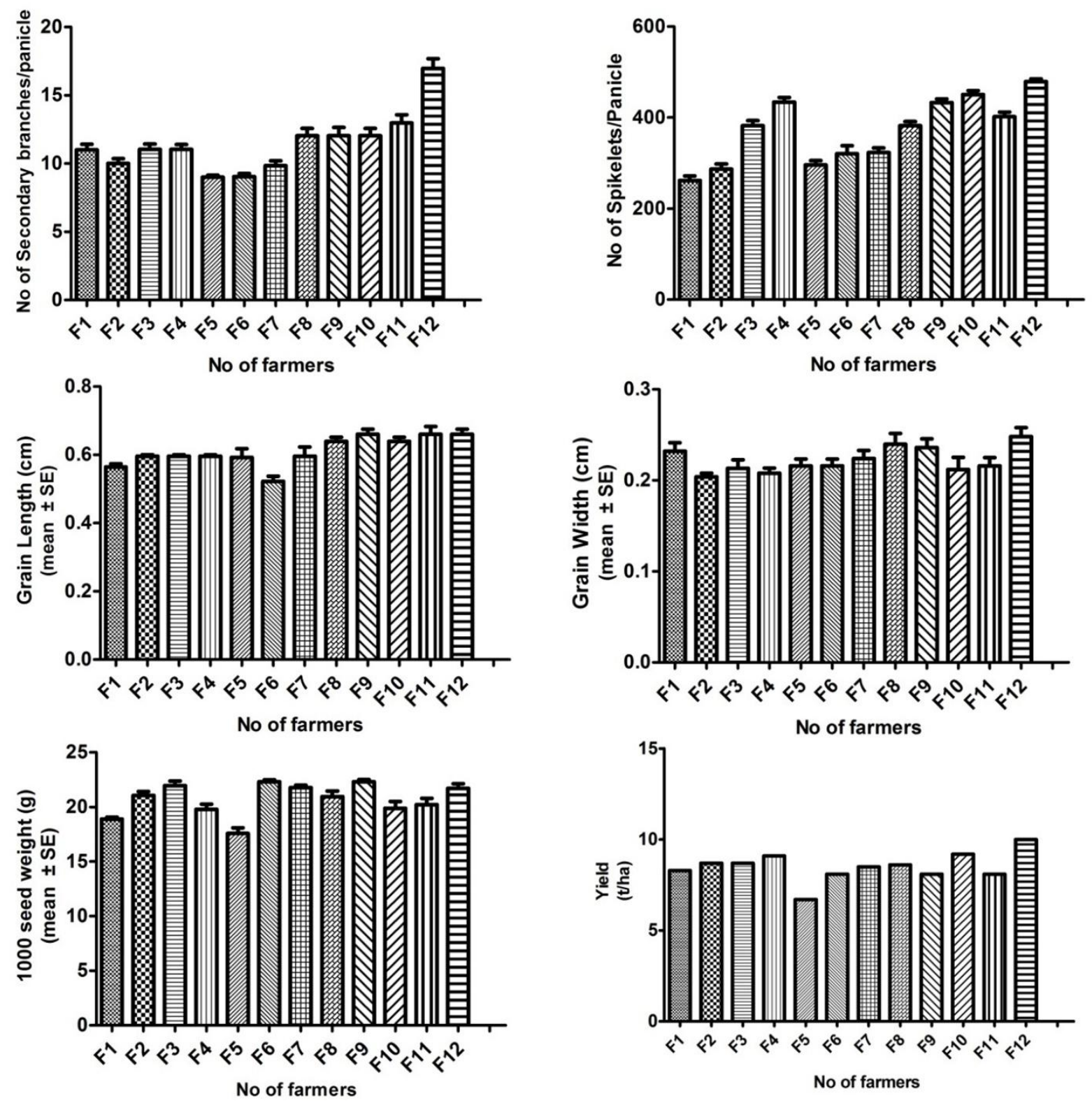

In 2014, the total area under the tested variety was 6.3 acres which increased to 24.0 acres in 2015 in two intervention villages where farmers started adopting it in the year 2015. In 2016 the total area under this variety increased to 63.14 acres spread across six districts of Gujarat through farmer to farmer dissemination of seeds (Figure 2). To increase local production, good quality seeds are prime requirement (Rickman et al., 2006) therefore farmers select varieties with traits that are desirable for consumption, production and sale as well as suited to environmental conditions and management practices (IRRI, 2009). Good quality seeds help farmers to maximize return in terms of short-term and long term production by ensuring high rate of survival, fast growth, low infection by pests and diseases by making best use of available land (Tokpah, 2010) hence locale specific technologies may play role in trade-offs (Klapwijk et al., 2014). Yokouchi and Saito (2016) suggested that farmer-to-farmer seed exchange need to be enhanced as observed in the current study there was a huge demand for the seeds of this variety amongst the farmers and the acreage increased more than 80 percent across six districts in just two years. Hence, identification and demonstration of such technologies are paramount. 


\section{Figure 2: Adoption of DRK paddy variety among farmers of Gandhinagar (Gujarat) during 2014-16.}

70

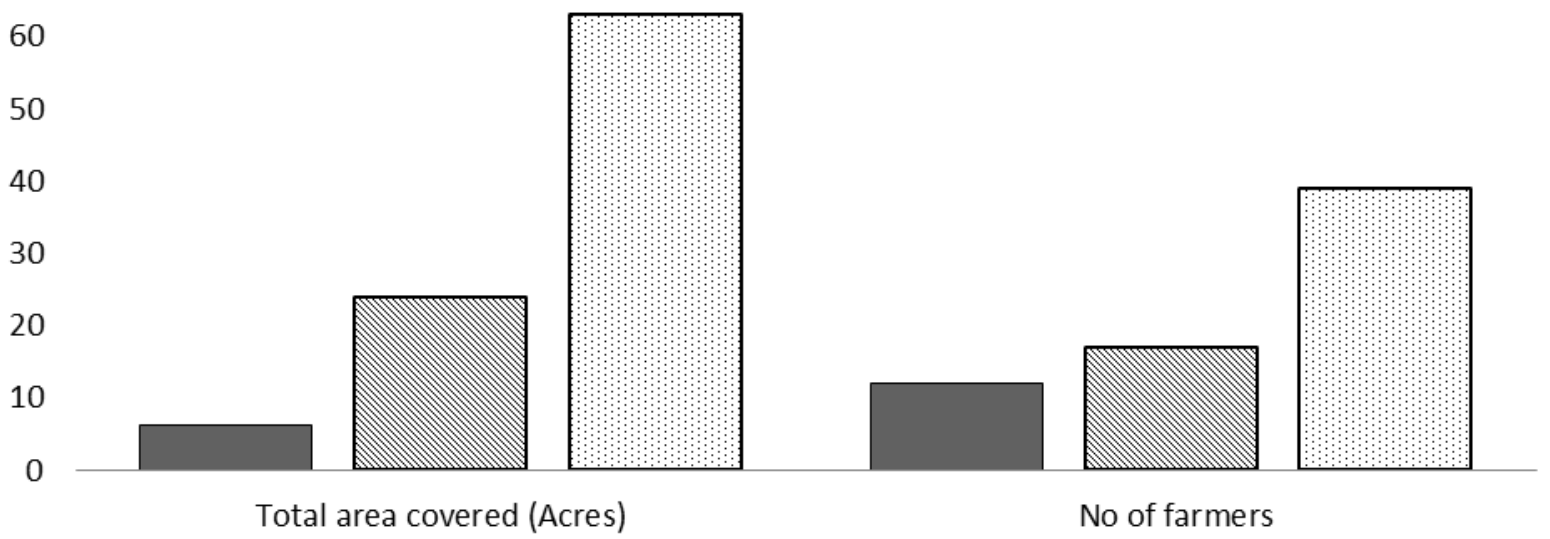

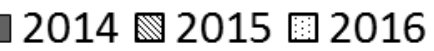

\section{Conclusions:-}

The study confirms that farmer's variety exhibited superior performance in terms of yield and yield attributing traits as well as better adaptation. Farmers' selection of crop varieties is based on their yield, market value and tolerance to biotic and abiotic stresses. In the current study, the discussions and meetings with farmers played an important role in its spread and adoption among six different districts across the state of Gujarat. The need of the hour is to strengthen the networking between the formal agencies of extension of the government and the farmer groups so that the sustainable varieties like DRK could be disseminated on a larger scale. The better reflections of different agronomic characters have been found in tested rice variety which can be further strengthened by integration of inputs from the formal scientific community as well as the participation of agencies like ATMA (Agricultural Technology Management Agency), ATIC (Agricultural Technology Information Centers) to strengthen the linkages between researchers and farmers for validation, adoption and dissemination of locally suited innovative grassroots technologies like DRK.

\section{Acknowledgments:-}

The authors express their sincere gratitude to Shri. Dadaji Ramji Khobragade for providing the seeds of DRK and to the farmers of Gandhinagar district who volunteered to conduct the study on their fields. We also thank Dr. Vipin Kumar, Director, National Innovation Foundation-India, (Autonomous Body of Department of Science and Technology, Government of India) for his constant support and valuable inputs.

\section{References:-}

1. Akram, M., Rehman, A. and Cheema, A. A. (1982): Correlation between yield and yield attributing characters in some induced dwarf mutants of rice (Oryza sativa L,). Pakistan J. Agric. Res., 3(3): 141 - 144.

2. Anbanandan, V., Sarvanan, K. and Sabesan, T. (2009): Variability, heritability and genetic advance in rice (Oryza sativa L.). Int. J. Plant Sci., 4(1): 61-66.

3. Anonymous, (2007).Agrifacts, (www.agric.gov.ab.ca)

4. Anonymous, (2007): Albert Agriculture and Food; Using 1,000 Kernel Weight for Calculating Seeding Rate and Harvest Losses; Available on line at http//www1 .agric.gov.ad/\$department/deptdocs.nfs/all/agdex8

5. Anonymous, (2007): Guidelines for the conduct of test for Distinctiveness, Uniformity and Stability on Rice (Oryza sativa.L). Protection of plant varieties and Farmers rights Authority, Govt. of India. http://www.plantauthority.gov.in/pdf/GRice.pdf

6. Bala Ravi, S. (2004): Manual on Farmers' Rights. M. S. Swaminathan Research Foundation. Chennai, India.

7. Chandrasekaran, B., Annadurai, K. and Kavimant, R. (2007): A textbook of rice science, Tamil Nadu Agricultural University, Coimbatore, pp 46-47-667, ISBN: 81-7233-466-4.

8. Cullet, P. and Koluru, R. (2002): "Plant Variety Protection and Farmers' Rights: Towards a Broader Understanding,” 24 Delhi Law Review, pp. 41. 
9. Dutta, P., Dutta, P.N. and Borua, P.K. (2013): Morphological traits as selection indices in rice: a statistical view. Universal J. Agric. Res., 1(3): 85-96.

10. Eswara Reddy, G., Suresh, B.G., Sravan, T. and Ashok Reddy, T. (2013): Interrelationship and cause-effect analysis of rice genotypes in north eastern plain zone. The Bioscan, 8(4): 1141-1144.

11. Ghimire, R., Wen-Chi, H. and Srestha, R. B. (2015): Factors Affecting Adoption of Improved Rice Varieties among Rural Farm Households in Central Nepal. China National Rice Research Institute. Rice Sci., 22(1): $35-43$.

12. Gupta, A.K. (2013): Tapping the entrepreneurial potential of grassroots innovation. Stanford Social Innovation Review, 11(3): 18-20.

13. INDIASTAT : Minimum Support Price for Foodgrains (Fair Average Quality) in India (1975-1976 to 20152016) (http://www.indiastat.com/agriculture/2/agriculturalprices/6527/minimumsupportprices/17827/stats.aspx)

14. INDIASTAT-India's Comprehensive Statistical Analysis Data (http://www.indiastat.com/agriculture/2/agriculturalarealanduse/152/areaundercrops19502015/448934/stats.asp $\mathrm{x})$

15. International Rice Research Institute (IRRI), (2006): Bringing hope, improving lives: Strategic Plan 2007-2015. Manila. pp 61.

16. International Rice Research Institute (IRRI), (2009): Introduction to Seed Management; Available at http//www.knowledgebank.irri.org/qualityseed.

17. IRRI, (1988): Standard evaluation system for rice. The International rice testing program. $3^{\text {rd }}$ Edition, The International Rice Research Institute, Los Banos, Philippines.

18. Jambhulkar, N.N. and Bose, L.K. (2014): Genetic variability and association of yield attributing traits with grain yield in upland rice. Genetika, 46(3): 831-838.

19. Jeng, T.L., Tseng, T.H., Wang, C.S., Chen, C.L. and Sung, J.M. (2006): Yield and grain uniformity in contrasting rice genotypes suitable for different growth environments. Field Crop Res., 99: 59-66.

20. Kadivendi, M., Maheshwari, R., Ravikumar, R.K., Chauhan, M.M., Kinhekar, A.S., Kumar, V. and Kumar, V. (2015): Integrated approach for engaging farming community -Opportunities and challenges for low cost inputs. Int. J. Agri. Innov. Res., 3(6): 1691-1695.

21. Karim, D., Sarkar, U., Siddique, M.N.A., Khaleque Miah, M.A. and Hasnat, M.Z. (2007): Variability and genetic parameter analysis in aromatic rice. Int. J. Sust. Crop Prod. , 2(5): 15-18.

22. Kaur, A. and Dhaliwal, L.K. (2014): Growth parameters and yield attributing characters PR-118 (V1) and PR116 (V2) varieties of rice (Oryza sativa L.) as influenced by different planting methods. J. Natural Appl. Sci., 6(2): 755-762.

23. Klapwijk, C.J., Wijk, MT van, Rosenstock, T.S., Asten, PJA van, Thornton, P.K. and Giller, K. E. (2014): Analysis of trade-offs in agricultural systems: current status and way forward. Curr. Opinion Env. Sust., 6: 110115.

24. Kuo, Y-C and Li, C- P., (1994): Genetic analysis of Leaf length and width of flag leaf in Rice. J. Agric. Res. China, 43(2): 123-134.

25. Lushington, K. (2012): The Registration of Plant Varieties by Farmers in India: A Status Report. Rev. Agrarian Studies 2(1): 112-128.

26. Manzoor, Z., R.I. Ali, T.H. Awan, N. Khalid and Mushtaq, A. (2006): Appropriate time of nitrogen application of fine rice Oryza sativa. J. Agric. Res., 44 (4): 261-267.

27. NIF database (2005): third national technological innovations \& traditional knowledge awards. http://nif.org.in/innovation/hmt--an_improved_paddy_variety/286.

28. NIF database (2009): Fifth National Grassroots Innovation Awards 2009. http://nif.org.in/upload/innovation/5th/68-diffusion-drk-paddy-variety.pdf

29. Ntanos, D.A. and Koutroubas, S.D. (2002): Dry matter and N accumulation and translocation for Indica and Japonica rice under Mediterranean conditions. Field crops Res., 74: 93-101.

30. Prajapati, M.K., Singh, C.M., Suresh Babu, G., Roopa Lavanya, G. and Jadhav, P. (2011): Genetic parameters for grain yield and its component characters in rice. Electron. J. Plant Breed., 1(3): 235-238.

31. Rickman, J. F., Bell, M., and D. Shires. (2006): Seed Quality. Available at http// www.knowledgebank.irri.org

32. Shiva V., Ramprasad V., Hegde, P., Krishnan, O., and HollaBhar R. (1995): The Seed keepers. Navdanya, New Delhi, pp 156.

33. Singh, B., Mishra, M.K., and Naik, R.K. (2010): Genetic diversity among some traditional aromatic rice (Oryza sativa L.) varieties of Orissa. Ind. J. Agric. Res., 44(2): 141-145.

34. Singh, S.K., Singh C.M. and Lal, G.M. (2011): Assessment of genetic variability for yield and its component characters in rice (Oryza sativa L.). Res. Plant Bio., 1(4): 73-76. 
35. Smith, C.W. and Dilday, R.H.(2003): Rice: Origin, history, technology, and production. $1^{\text {st }}$ Ed. Published by John Willey \& Sons, Inc., Hoboken, New Jersey.

36. Statista- The Statistical Portal (http://www.statista.com/statistics/271969/world-rice-acreage-since-2008/).

37. Surek, H., and Beşer, N., (1996): A Research to Determine the Suitable Rice (Oryza sativa L.) Harvesting Time. J. Agric. Fore., 22: 391-394.

38. Tokpah, E.S. (2010): Seed and grain quality characteristic of some rice varieties in Ghana.Thesis.pp:1-53. (ir.knust.edu.gh/bitstream/123456789/787/1/ERIC\%20S.\%20TOKPAH.pdf)

39. Tyagi, A. K., Khuran, J. P., Khurana, A. P., Raghubanshi, S., Gour, A., Kapur and A., Sharma, S. (2004): Structural and functional analysis of rice genome. J. Genet, 83: 79-99. (http://dx.doi.org/10.1007/BF02715832).

40. Yokouchi, T and Saito, K. (2016): Factors affecting farmers' adoption of NERICA upland rice varieties: the case of a seed producing village in central Benin. Food Security, 8 (1): 197-209

41. Zeng, L. and Shannon, M.C. (2000): Salinity effects on seedling growth and yield components of rice. Crop Sci., 40: 996- 1003. 